\title{
A Randomized Trial to Determine the Efficacy of Dry Versus Wet Misoprostol for Termination of First Trimester Pregnancy
}

\author{
Mahaseth BK, Singh M, Rawal S \\ TU Teaching Hospital, Maharajganj, Kathmandu Nepal
}

\begin{abstract}
Aims: To asses, the efficacy of dry versus wet misoprostol for termination of first trimester pregnancy with respect to complete abortion rate

Methods: Study Design: Randomized Clinical Trial. Setting: Department of Obstetrics and Gynaecology, Tribhuvan University Teaching Hospital, Institute of Medicine Maharajgunj, Kathmandu, Nepal. Period: This was conducted over 12 month's period, from 20th Mangsir 2062 to 2063 (5th December 2005 to 2006). Participants: 100 women within 74 days of pregnancy were divided into two groups A and B depending on the gestational age (group A $\leq 49$ days and in group B $>49$ days of gestation). Group A and B were further randomized into two subgroup A1 (dry), A2 (wet) and B1 (dry), B2 (wet) randomly by making them choose envelope. Misoprostol $800 \mu \mathrm{g}$ was given on day 1 and same dose was repeated on day 3 if abortion was incomplete or pregnancy continued after the first dose. All the women were examined on day 10 (one week after second dose) for incomplete abortion or failure to abort, where MVA was carried out if needed. Outcomes measures were comparison of complete abortion rate of dry versus wet misoprostol.
\end{abstract}

Results: Among 100 women 89 (89\%, 81.21 -93.91 CI of 945\%) aborted successfully. Out of 100 women 65 (65\%, 52.24 -73.65 CI of $945 \%$ ) aborted with one dose of misoprostol. Remaining 35 received second dose out of which 24 women aborted successfully with second dose and remaining 11 underwent manual vacuum aspiration (MVA). In dry group 42 (84\%) and in wet group 47 (94\%) aborted. In group A 45(90\%) and in group B 44 (88\%) women aborted. Side effects were abdominal pain in $89 \%$ and vaginal bleeding in $90 \%$ of women.

Conclusions: Vaginal misoprostol $800 \mu \mathrm{g}$ given on day 1 and same dose repeated on day 3 was found to have better efficacy than single dose for medical termination of first trimester pregnancy, wet preparation having slightly better results with acceptable side effects.

Keywords: Dry versus wet misoprostol, medical abortion, manual vaccum aspiration

\section{INTRODUCTION}

Medical termination of pregnancy has gained popularity after the legalization of abortion law. Medical abortion refers to abortion effected by medication alone by using either mifepristone and misoprostol or only misoprostol. Misoprostol is a synthetic analogue of prostaglandin E1 which by acting through endogenous EP-2 or EP-3 prostanoid receptor in myometrium results in softening of cervix with uterine contraction.

Misoprostol, known for exerting main expulsive action by the uterus after the conceptus is detached from uterine wall by mifepristone, has been utilized for medical termination of pregnancy as an alternative and effective regimen. ${ }^{1-3}$ But the results were not as encouraging as they were when used in combination. Therefore to increase the efficacy of misoprostol different dosing pattern were adopted by administrating in different routes: sublingual, buccal, oral and vaginal; the tablet being moistened before vaginal application since the nineties by various authors. ${ }^{1,5}$

Vaginal route currently is the most widely used route and has been found to be more effective after wetting the tablet with water before insertion in order to increase slower but more constant absorption through vaginal mucosa. ${ }^{6}$

In this context, this study aims at finding whether vaginal misoprostol $800 \mu \mathrm{g}$ in dry versus wet form will provide termination of unwanted pregnancy up to 74 days as an alternative choice of medical abortion method.

\section{CORRESPONDENCE}

Dr. Binod K Mahaseth, MD

Department of Obstetrics and Gynaecology

Nepalganj Medical College

Phone : 9841414208

Email : mahaseth.binod@yahoo.com 


\section{METHODS}

Study Design: Randomized Clinical Trial. Setting: Department of Obstetrics and Gynaecology, Tribhuvan University Teaching Hospital, Institute of Medicine Maharajgunj, Kathmandu, Nepal. Period: This was conducted over 12 month period, from $20^{\text {th }}$ Mangsir 2062 to 2063 (5th December 2005 to 2006). Participants: 100 women within 74 days of pregnancy were divided into two groups $A$ and $B$ depending on the gestational age (group $A \leq 49$ days and in group $B>49$ days of gestation). Group $A$ and $B$ were further randomized into two subgroup $A_{1}$ (dry), $A_{2}$ (wet) and $B_{1}$ (dry), $B_{2}$ (wet) randomly by making them choose envelope. Misoprostol $800 \mu \mathrm{g}$ was given on day 1 and same dose was repeated on day 3 if abortion was incomplete or pregnancy continued after the first dose. All the women were examined on day 10 (one week after second dose) for incomplete abortion or failure to abort, where MVA was carried out if needed. Outcomes measures were comparison of complete abortion rate of dry versus wet misoprostol.

\section{RESULTS}

Age of women ranged from 20-35 years belonging to different age groups such as; 25 -29 (35); 30-35 (35); 20-24 (7) and less than 20 (3). Ninety seven percent of women were Hindu and $3 \%$ were Buddhist. Primigravida was (14\%) rest were multigravida (86\%): Gravida 2(21\%), Gravida 3 (19\%); Gravida 4 (20\%) and Gravida 5 (19\%). With regards to parity the distributions were as follows: Nulli-para or Para 0 (15\%); para 1 (24\%); Para 2 (35\%); Para 3 (16) and Para 4 (10\%). Gestational age was determined and reconfirmed by TVS in Group A (57\%) and B (43\%) as dating was generally used from LMP in Group A (47\%) and Group B (53\%).

Overall success rate as shown by complete abortion was 89 (89\%, $95 \% \mathrm{Cl}, 81.21-93.91)$ and 65 out of 89 aborted with first dose of misoprostol which occurred in both the groups [in Group A 36(72\%) and in Group B 29 (58\%)]. Thirty-five women (35\%) required second dose of tablet misoprostol resulting in further recorded abortion 24 in number except for the $11 / 100(11 \%, 6.09-18.79 \mathrm{Cl} 95 \%)$ cases that required MVA (Table 1 ). The overall success rate among Group A: 45/50 (90\%, $95 \% \mathrm{Cl} 78.21-96.09)$ is comparable to Group B 44 /50 (88\%, 95 \% Cl 75.83-94.75). (Table 2)

The response was better with wet than dry misoprostol as number of women in the said group $A_{1} B_{1}$ (dry) required MVA as seen in the result [ $A_{1}$ group, $21(84 \%, 95 \% \mathrm{Cl} 64.73-$ 94.21), and in $A_{2}$ group 24 (96\%, 95\% Cl 78.86-99.99) completely aborted and in $\mathrm{B}_{1}$ group 21 (84\%, 95\% Cl 64.7394.21) and in $\mathrm{B}_{2}$ group 23 (92\%, $\left.95 \mathrm{Cl} 73.90-98.91\right)$ had complete abortion (Table 3).

Table 4 details 100 women, 65(65\%) aborted with single dose of tablet misoprostol which included all the 14 primigravida, latter irrespective of the status of the preparation whether dry or wet $\left[\left(A_{1} B_{1)}\right.\right.$ or $\left.A_{2} B_{2}\right]$. In multigravida out of 86 women 51 aborted with single dose and in the recipient of 2 doses of misoprostol 35 [24 (aborted); MVA done in $11\left\{8\left(A_{1} B_{1}\right.\right.$ Group) and 3 in $\left(A_{2} B_{2}\right.$ Group)\}].

Table 1. Complete abortion and need for surgical evacuation

\begin{tabular}{llllcl}
\hline Outcome & Dose & No & $\%$ & Cl & $\begin{array}{l}\text { P } \\
\text { value }\end{array}$ \\
\hline Complete & 1st dose & 65 & 65 & $52.24-73.65$ & \\
abortion & 2nd dose & 24 & 24 & $51.92-81.55$ & 0.79 \\
& Total & 89 & 89 & $81.21-93.91$ & \\
Required MVA & & 11 & 11 & $6.09-18.79$ & \\
\hline
\end{tabular}

Table 2. Successful abortion in both groups

\begin{tabular}{|c|c|c|c|c|c|c|}
\hline \multirow[t]{2}{*}{ Details } & \multicolumn{2}{|c|}{$\begin{array}{l}\text { Group A: } \\
\text { POG } \leq 49 \text { Days } \\
(n=50)\end{array}$} & \multirow[b]{2}{*}{$\mathbf{p}$} & \multirow[b]{2}{*}{ No } & \multicolumn{2}{|c|}{$\begin{array}{l}\text { Group B: } \\
\text { POG > } 49 \text { Days } \\
(n=50)\end{array}$} \\
\hline & No. & $95 \% \mathrm{Cl}$ & & & $95 \% \mathrm{Cl}$ & $p$ \\
\hline $\begin{array}{l}\text { Aborted } \\
\text { with }\end{array}$ & $\begin{array}{l}45 \\
(90 \%)\end{array}$ & $\begin{array}{l}78.21- \\
96.09\end{array}$ & & $\begin{array}{l}44 \\
(88 \%)\end{array}$ & $\begin{array}{l}75.83- \\
94.75\end{array}$ & \\
\hline 1 st d & $\begin{array}{l}36 \\
(72 \%)\end{array}$ & $\begin{array}{l}58.24- \\
82.62\end{array}$ & 0.34 & $\begin{array}{l}29 \\
(58 \%)\end{array}$ & $\begin{array}{l}44.22- \\
70.64\end{array}$ & 0.66 \\
\hline $\begin{array}{l}\text { 2nd } \\
\text { dose }\end{array}$ & $\begin{array}{l}9 \\
(18 \%)\end{array}$ & $\begin{array}{l}9.54- \\
31.02\end{array}$ & & $\begin{array}{l}15 \\
(30 \%)\end{array}$ & $\begin{array}{l}19.03- \\
43.83\end{array}$ & \\
\hline $\begin{array}{l}\text { Required } \\
\text { MVA }\end{array}$ & $\begin{array}{l}5 \\
(10 \%)\end{array}$ & $\begin{array}{l}3.91- \\
21.79\end{array}$ & & $\begin{array}{l}6 \\
(12 \%)\end{array}$ & $\begin{array}{l}5.25- \\
24.17\end{array}$ & \\
\hline
\end{tabular}

Table 3. Abortion in dry and wet group

\begin{tabular}{|c|c|c|c|c|c|}
\hline \multicolumn{2}{|c|}{ Outcome } & \multicolumn{2}{|c|}{$\begin{array}{l}\text { Group A: } \\
\text { POG } \leq 49 \text { Days } \\
(n=50)\end{array}$} & \multicolumn{2}{|c|}{$\begin{array}{l}\text { Group B: } \\
\text { POG > 49 Days } \\
(n=50)\end{array}$} \\
\hline \multicolumn{2}{|c|}{ Sub group } & $\begin{array}{l}\text { A1 } \\
(n=25)\end{array}$ & $\begin{array}{l}A 2 \\
(n=25)\end{array}$ & $\begin{array}{l}B 1 \\
(n=25)\end{array}$ & $\begin{array}{l}\text { B2 } \\
(n=25)\end{array}$ \\
\hline \multirow[t]{3}{*}{$\begin{array}{l}\text { Aborted } \\
\text { with }\end{array}$} & $1^{\text {st }}$ dose & $\begin{array}{l}15 \\
(60 \%)\end{array}$ & $\begin{array}{l}21 \\
(84 \%)\end{array}$ & $\begin{array}{l}10 \\
(40 \%)\end{array}$ & $\begin{array}{l}19 \\
(76 \%)\end{array}$ \\
\hline & $2^{\text {nd }}$ dose & $\begin{array}{l}6 \\
(60.0 \%)\end{array}$ & $\begin{array}{l}3 \\
(75.0 \%)\end{array}$ & $\begin{array}{l}11 \\
(73.3 \%)\end{array}$ & $4(16 \%)$ \\
\hline & Total & $\begin{array}{l}21 \\
(84 \%)\end{array}$ & $\begin{array}{l}24 \\
(96 \%)\end{array}$ & $\begin{array}{l}21 \\
(84 \%)\end{array}$ & $\begin{array}{l}23 \\
(92 \%)\end{array}$ \\
\hline \multicolumn{2}{|c|}{ Required MVA } & $4(16 \%)$ & $1(4 \%)$ & $4(16 \%)$ & $2(66 \%)$ \\
\hline
\end{tabular}

Table 4. Response of misoprostol in primi vs multigravida

\begin{tabular}{llcccc}
\hline Gravida & & \multicolumn{2}{c}{$\begin{array}{c}\text { Primigravida } \\
\mathrm{n}=14\end{array}$} & \multicolumn{2}{c}{$\begin{array}{c}\text { Multigravida } \\
\mathrm{n}=86\end{array}$} \\
\hline $\begin{array}{l}\text { Random- } \\
\text { ized Grp }\end{array}$ & $\begin{array}{l}\text { Miso } \\
\text { prostol }\end{array}$ & $\begin{array}{c}\text { Dry } \\
(\mathrm{n}=6)\end{array}$ & $\begin{array}{c}\text { Wet } \\
(\mathrm{n}=8)\end{array}$ & $\begin{array}{c}\text { Dry } \\
(\mathrm{n}=6)\end{array}$ & $\begin{array}{c}\text { Wet } \\
(\mathrm{n}=8)\end{array}$ \\
& & $\begin{array}{c}100 \% \\
100 \%\end{array}$ & 19 & 32 \\
Aborted & 1st dose & 0 & 0 & $\begin{array}{c}(61 \%) \mathrm{h} \\
(83 \%)\end{array}$ \\
with & & & & 17 & 7 \\
& 2nd dose & 0 & 0 & $(53 \%)$ & $(57 \%)$ \\
MVA & & & & 8 & 3 \\
Required & 0 & 0 & $(51 \%)$ & $(43 \%)$ \\
\hline
\end{tabular}


Table 5. Failure to abort after two doses

\begin{tabular}{cccc}
\hline Gravida & \multicolumn{2}{c}{ Misoprostol } & Total \\
& Dry & Wet & \\
\hline G1 & 0 & 0 & 0 \\
G2 & 2 & 0 & 2 \\
G3 & 3 & 1 & 4 \\
G4 & 2 & 2 & 4 \\
G5 & 1 & 0 & 1 \\
\hline Total & $\mathbf{8}$ & $\mathbf{3}$ & $\mathbf{1 1}$ \\
\hline
\end{tabular}

Table 6. Period of gestation in realtion to misoprostol

\begin{tabular}{|c|c|c|c|c|c|}
\hline $\begin{array}{l}\text { POG in } \\
\text { days }\end{array}$ & Number & Dry 1 & $\begin{array}{l}\text { Wet } \\
2 \\
\end{array}$ & $\begin{array}{l}\text { Sucessful } \\
\text { abortion }\end{array}$ & $\begin{array}{l}P \\
\text { Value }\end{array}$ \\
\hline $\begin{array}{l}\text { Grp A= } \\
\leq 49\end{array}$ & 50 & $\begin{array}{l}21 \\
(84 \%)\end{array}$ & $\begin{array}{l}24 \\
(96 \%)\end{array}$ & $\begin{array}{l}45 \\
(90 \%)\end{array}$ & 0.412 \\
\hline Grp B>49 & 50 & $\begin{array}{l}21 \\
(84 \%) \\
\end{array}$ & $\begin{array}{l}23 \\
(92 \%) \\
\end{array}$ & $\begin{array}{l}44 \\
(88 \%) \\
\end{array}$ & \\
\hline Total & 100 & $\begin{array}{l}42 \\
(84 \%)\end{array}$ & $\begin{array}{l}47 \\
(94 \%)\end{array}$ & $89 \%$ & \\
\hline
\end{tabular}

Gestational age hardly contributed on successful abortion as all primigravida were observed to carry $100 \%$ success rate just with a single dose of misoprostol, followed by gravida 5 (94.73\%). The success rate was lowest in gravida $4(80 \%)$ while in gravida 3 it was $(84.61 \%)$ and gravida 2 $(90.47 \%)$, while it was not so with gravida 5 . Medical abortion failed in various gravidas (G2, G2, G3, G4 and G5) that ranged from 1-4\% (Table 5). Wet preparation is sought to be better than dry in consideration to gestational age, but without having any statistical significance (Table 6).

Minor side effects like headache (5\%), nausea (12\%), vomiting (6\%) and diarrhea (4\%) giving satisfaction with the method up to $93 \%$.

\section{DISCUSSION}

Misoprostol alone as an abortificient has been proven to be an important regimen with the proclaimed success rate up to $97 \%$ in different protocol in varied gestational age. ${ }^{1-9}$ The successful abortion rate of $89 \%$ in this study is similar to that obtained by many adhering to same treatment protocol. ${ }^{5-8}$ A marginal reported success rates increase from $87 \%$ to $92 \%$ achieved. ${ }^{6,8,10,11}$ This was possible by increasing vaginal misoprostol $800 \mu \mathrm{g}$ to three doses and decreasing the gestation age to $\leq 56$ and $\leq 63$ days pregnancy. ${ }^{4}$ Successful abortion rate for termination of $\leq$ 10 weeks pregnancy has been also advocated with three doses of $800-\mu \mathrm{g}$ vaginal misoprostol, and an extra dose of $400 \mu \mathrm{g}$ and $600 \mu \mathrm{g}$ oral misoprostol for incomplete abortion depending on the amount of retained tissue inside uterine cavity. ${ }^{3,6,7,10}$ Use of extra dose may be the reason for higher success rate.
Most studies have demonstrated the success rate ranging from $64 \%$ to $77 \%$ after first dose of vaginal misoprostol. These studies had included the pregnancies of $\leq 63$ days of gestation while in our study, pregnancy up to 74 days of gestation were included. Inclusion of gestational age up to 74 days provided group B with lesser success. The efficacy of misoprostol decreases as pregnancy advances ${ }^{6,12-14}$

Moistening misoprostol before vaginal application has given better results. ${ }^{11}$ There are several studies to its credit. One such study was where methotrexate/placebo was given in day 1 followed by a single dose vaginal tablet of $800-\mu \mathrm{g}$ misoprostol in both groups for medical abortion of $<63$ days of gestation. ${ }^{15}$

Use of 3 doses of $800-\mu \mathrm{g}$ misoprostol applied vaginally on day 1, 3, and 5 gave success rate of wet:dry as $85 \%: 65 \%$ by day $15 .{ }^{9}$ As the efficacy of third dose of misoprostol was observed to improve abortion rate only by $0.6 \%-6.1 \%$, we just adopted 2 doses regimen. This has further helped to shorten the follow up days $.6-8,10$

An important highlight of this study is that $100 \%$ of the primigravida aborted successfully with a single dose of misoprostol with tolerable side effects. One thing we could have done better was noting the time taken for expulsion of conceptus.

Despite the current WHO-recommended medical regimen for early medication abortion with combined use of tablet mifepristone and misoprostol, we have found favourable results with the use of vaginal misoprostol alone.

\section{CONCLUSIONS}

Vaginal misoprostol $800-\mu \mathrm{g}$ is effective and safe for termination of gestation $\leq 74$ days. Two doses of misoprostol are better than a single dose with the advantage of higher complete abortion rate by decreasing the need of surgical method using manual vacuum aspiration. Wet misoprostol in comparison to dry is found better. However it would be appropriate to do a larger study to conclude that wet misoprostol is more effective than dry misoprostol for termination of first trimester pregnancy.

\section{REFERENCES}

1. Blanchard K, Winiko B, Ellertson C. Misoprostol used alone for the termination of early pregnancy. (A review of the evidence). Contraception 1999; 59: 209-17

2. Velazco A, Varela L, Tanda R, Sanchez C, Barambio S, Chami S et all. Misoprostol for abortion up to 9 weeks' gestation in adolescents. Eur J Contracept Reprod Health Care 2000; 5(4): 227-33.

3. Tang OS, Miao BY, Lee SW, Ho PC. Pilot study on the use of repeated doses of sublingual misoprostol in termination of pregnancy up to 12 weeks gestation: efficacy and acceptability. Hum Reprod 2002; 17(3): 654-8.

4. Zikopoulos KA, Papanikolaou EG, Kalantaridou SN, Tsanadis GD, Plachouras NI, Dalkalitsis NA, et all. Early pregnancy termination with vaginal misoprostol before and after 42 days gestation. Hum Reprod 2002; 17(12):3079-83. 
5. Bugalho A, Faundes A, Jamisse L, Usfa M, Maria E, Bique C. Evaluation of the effectiveness of vaginal misoprostol to induce first trimester abortion. Contraception1996; 53(4): 244-6.

6. Carbonell JLL, Varela L, Valazco A, Fernandez C. The use of misoprostol for termination of early pregnancy. Contraception1997; 55:165-8

7. Singh K, Fong YF, Dong F. A viable alternative to surgical vacuum aspiration: Repeated doses of intravaginal misoprostol over 9 hours for medical termination of pregnancies up to eight weeks. BJOG 2003; 110(2): 175-80).

8. Salakos N, Kountouris A, Botsis D, Rizos D, Gregoriou O, Detsis G ,et al. First trimester pregnancy termination with $800 \mu \mathrm{g}$ vaginal misoprostol every 12 hours. Eur J Contracept Reprod. Health Care 2005; 10(4): 249-54.

9. Ngai SW, Tang OS, Chan YM, Ho PC. Vaginal misoprostol alone for medical abortion up to 9 weeks of gestation: Efficacy and acceptability. Hum Reprod 2000; 15(5):1159-62.

10. Carbonell Esteve JL, Varela L, Velazco A, Cabezas E, Tanda R, Sanchez C. Vaginal misoprostol for late first trimester abortion. Contraception 1998; 57(5): 329-33.
11. Jain JK, Meckstroth KR, Mishell DR Jr. early pregnancy termination with intravaginally administered sodium chloride solutionmoistened misoprostol tablets: Historical comparison with mifepristone and oral misoprostol. Am J Obstet Gynecol 1999; 181(6): 1386-91

12. World Health Organization Task force on postovulatory methods of fertility regulation special programme of research development and research training, World Health Organization, Geneva. Comparison of two doses of mifepristone in combination with misoprostol for medical abortion: A randomize clinical trial. Br J Obstet Gynecol 2000; 107: 524-30.

13. Kapp N, Borgatta L, Ellis SC, Stubblefield P. Simultaneously very low dose mifeprostone and misoprostol for medical abortion up to 56 days of gestation. J Fam Plann Reprod Health Care. 2005; 31(3): 189-192.

14. Murthy AS, Crenin MD, Harwood B, Schreiber C. A pilot study of Miferpirostone and misoprostol administration at the same time for abortion up to 49 days of gestation. Contraception. 2005; 71 (5): 333-6.

15. Creinin MD, Vittinghoff E. Methotrexate and misoprostol vs. misoprostol alone for early abortion. A randomized controlled trial. JAMA. 1994; 272(15):1190-5. 